\title{
Mission Statements in Port Authorities: Empirical Analysis of Content in Spanish Port System
}

\section{Ignacio de la Peña Zarzueloa , María Jesús Freire-Seoane ${ }^{b}$, Beatriz López-Bermudez ${ }^{\mathrm{b}}$}

Introduction: A structured Strategic Planning process has been developed in the Spanish Port System since 1990s. One of the first elements of this process is the formulation of the mission statement of each Port Authority.

Aim: An in-depth review of the mission statements of the Spanish Port Authorities is carried out in this research, and mission statements are assessed from a theoretical point of view. The goal of the study is to discuss how mission statements of these entities are aligned with the international standards.

Methods: Mission statements are captured from public sources. Two criteria are used for the assessment: its content (analyzing if the mission statement reflects nine key elements usually considered internationally), and its length (number of words). As the first component is qualitative, a Delphi method was used in the assessment of this element.

Results: The mission statements of these Port Authorities reflect more frequently than the benchmark comparison made by over 50 companies seven of the nine key elements. The only two fields in which Spanish Port Authorities show a negative gap are those related to "technology" and "concern of employees". In terms of length, the average of 32 words is shorter than the $50-100$ words recommended by some authors.

Conclusions: The Strategic Planning in the Spanish Port Authorities is a long and well -structured process. Port Authorities are essentially market-oriented public organisms and their mission statements seems to be properly formulated following business practices in terms of their content.

\footnotetext{
a. Polytechnic University of Madrid, School of Civil Engineers

e-mail: i.delapena@upm.es

b. University of A Coruña, Department of Economy, Economy and Business Faculty e-mail: maria.freire.seoane@udc.es
}

doi: 10.7225/toms.v08.n02.009

This work is licensed under (cc) BY

\section{KEY WORDS}

$\sim$ Mission statement

$\sim$ Strategic plan

$\sim$ Port authority

$\sim$ Corporate identity

$\sim$ Port system

$\sim$ Content analysis

\section{Introduction}

"Organismo Público Puertos del Estado" (OPPE) is the Spanish Governmental Agency dependent on the Ministry for Development (formerly Ministry of Transport and Public Works) responsible for implementing the national Government's port policy in Spain. It also coordinates 28 Port Authorities (PA's) within Spanish territory. These PA's manage a total of 46 major ports. These are considered so-called "ports of general interest" (PGI's) of the Spanish Port System (SPS). Apart from these PGI's, other minor ports are controlled by different administrative entities dependent on different regional governments.

Article 52 of the Spanish State Ports and Merchant Marine Act (SPMA) (Royal Decree-Law 2/2011) lays out that according to the Government's economic and transport policy, the Ministry of Development will approve the model of strategic development, criteria of action as well as general objectives for the technical, economic, financial, and human resource management of the entire group of PGI's of SPS under the administrative umbrella of OPPE.

To this end, OPPE jointly with PA's will elaborate the Spanish Port Strategic Framework (SPSF), which will be ratified by the Board of OPPE and sent to the Ministry of Development for approval.

Additionally, Article 53 of SPMA states that in order to establish the development model and the strategic position of each Port Authority (PA), they may elaborate a Strategic Plan 
covering the ports of its competence, which should include at least: i) an analysis and diagnosis of the current situation, ii) the definition of their objectives and strategic lines, iii) their criteria of act and action plan.

This legal provision is in reality a recommendation and in no case an obligation. However, it is not a new determination since it also had appeared with exactly the same wording in Article 37 of Law 48/2003 which preceded the current SPMA, and it further developed the former previous State Ports and Merchant Marine Act dated 1992 (Law 67/1992).

Enríquez (1993) introduced Strategic Planning in the agenda of SPS with a practical implementation in Valencia PA, and OPPE approved in 1998 the first SPSF which was intended to be the basic common ground for the development of SPS from the strategic standpoint (Puertos del Estado, 2001).

As a result of all this legal and administrative background, most of the 28 PA's have elaborated their strategic plans, adopting international business practices and standards. Additionally, all of them: i) have drawn a Strategic Map (aligned with the strategic lines of SPSF), ii) have successfully implemented the Balance Scored Card following the requirement of OPPE, iii) a performance measurement software has been applied in the strategy planning process (SPP) (Estrada, 2007; Aparisi et al., 2009).

Recently, PA's started to make public its annual Sustainability and Corporate Social Responsibility Reports in which a specific section is dedicated to tackle SPP. In these annual reports, PA's reveal their mission statements (MS) as well as its vision and corporate values.

\section{Material and methods: literature review}

MS's are primarily based on the guidelines provided by Drucker $(1974,61)$ who was its pioneer proponent focusing on the relevance of a proper formulation of this first step in SPP.

King and Cleland $(1979,88)$ recommend organizations to write their MS to: i) make sure all employees and managers understand the firm's purpose or reason for being; ii) provide a basis for prioritization of key internal and external factors utilized to formulate feasible strategies; iii) provide a basis for the allocation of resources; and iv) provide a basis for organizing work, departments, activities, and segments around a common purpose.

Although MS's started to be explicitly formulated from early 1980s (Pearce, 1982; Pearce and David, 1987) and there is a general consensus about the importance of its proper formulation, researchers have paid poor attention to deeply analyze the issue from the theoretical point of view (Sashittal and Tankersley, 1997; Amato and Amato, 2002; David et al., 2014; Alegre et al., 2018).

Pearce (1982) defined the company mission as "a broadly defined but enduring statement of purpose that distinguishes a business from other firms of its type and identifies the scope of its operations in product and market terms." Similarly, other authors have defined MS as a written formal declaration that communicates the purpose of an organization (Bart and Hupfer, 2004; Macedo et al., 2016) and "the reason for being" of an organization (Pearce and David 1987; Campbell and Yeung 1991; David et al., 2014).

This first author provided a practical framework to be used in defining an adequate company mission, including recommendations for its content and a process of taking into consideration diverse, if not conflicting, demands placed on strategic direction. This work focused particularly on the social responsibility and its impact on MS.

Other authors have provided guidelines for developing the most appropriate MS. For instance, Lundberg (1984) described the Zero-in technique as a "structured group process which efficiently develops a consensual synthesized mission statement resulting in high commitment." Simplifying, this methodology is to make all key managers with major responsibilities within the company or corporation work together in a series of meeting and related activities in order to develop MS.

Developing a proper MS has been acknowledged to be as the very first step in any SPP (Pearce and David, 1987), and it is recognized as a powerful tool for formulating and implementing the organization's strategy if it is properly developed with the involvement of the top management group (Baetz and Bart, 1996).

First Pearce (1982) and later Pearce and David (1987) pointed out that the MS should be the most visible and public part of a strategic plan and suggested a guide for developing the most appropriate statements focusing on eight key elements:

- $\quad$ Customers and/or markets

- Products and/or services

- Core technologies

- Geographic domain

- Expression of commitment to survival, growth, and profitability

- Key elements in the company philosophy

- Company self-concept (distinctive competence)

- Firm's desired public image

These authors developed an empirical investigation to assess the relationship between: i) MS of a company, ii) inclusion of the eight key elements listed above, iii) corporate financial performance of these companies.

They carried out an intensive survey covering 500 companies among which 218 companies replied to the survey (44\%), while 282 companies did not send any response (56\%). The companies that replied to the survey, $40 \%$ of them (88 out of 218 ) did not have a proper MS, while $5 \%$ replied rejecting to send MS on the basis of confidentiality (11 out of 282). The remaining 
$27 \%$ (58 companies) did not provide a material that the authors could use consistently, and only $28 \%$ (61 companies) were companies with sufficient and clear information to be included in the study.

Throughout the examination of these 61 companies, the authors reached the conclusion that although it is clear that many variables will affect organizational performance, it is not unreasonable to demand empirical evidence of the presumed integral role of MS in linking SPP with corporate finance.

Further, David (1989) introduced a ninth key element to be included in the assessment, which is "concern for employees". This list of nine topics in MS has later been followed by many authors (Baetz and Bart, 1996; O'Goman and Doran 1999; Rajasekar, 2013; Alegre et al., 2018).

From the economic point of view, the topic of the content of MS and companies' financial performance has been revisited by many other authors as Germain and Cooper (1990), Kaplan and Norton (1992), Medley (1992), Rarick and Vitton (1995), Baetz and Kenneth (1998), Bart and Baetz (1998), Bart et al. (2001), Amato and Amato (2002), Green and Medlin (2003), Atrill et al. (2005), Bartkus et al. (2006), Palmer and Short (2008), Hirota et al. (2010), Desmidt et al. (2011), Genç (2012), Pradeep et al. (2012), Macedo et al. (2016).

Capon et al. (1990) further studied factors affecting the financial performance of companies. They carried out a metaanalysis covering 320 empirical studies covering the period 1921-1987, and they took into consideration environmental, organizational as well as strategic factors (as those included in MS).

As the goal of this work is concerned: i) The American Association of Port Authorities had published a pioneer guideline for the development of SPP in the maritime industry (APPA, 1998), ii) in the context of a work focused in SPP in PA's, the United Nations Conference on Trade and Development (UNCTAD) had paid attention to the different levels of the planning process in port management, and it had identified short and long term processes UNCTAD (1993). UNCTAD highlighted that MS, vision and corporate values are key elements to be formally adopted with long term perspective.

More simplistically than other authors, Bart (1997) states that MS should have three components: i) key market (or target audience), ii) contribution of the product or service, and iii) distinction of the company.

Campbell (1997) considers that MS became an obligatory part of a company's portfolio of literature along with a statement on environmental policy and a commercial brochure selling the company.

Leuthesser and Kohli (1997) state that MS can provide a consistent message about all facets of a firm to the various public concerned and more broadly define the corporate entity as the way in which an organization reveals its philosophy and strategy through communication, behavior, and symbolism.

The need of the involvement of top management in the definition and implementation of MS has been further addressed by Mullane (2002). This author states that the approach that managers take regarding MS formulation is a key issue, and he differentiated the managers according to their loyalty to MS. The author points out that while "some managers swear by their mission statement", others "swear at theirs". There are managers that understand MS usefulness and they use it to influence the inner working, while others take a passive approach expecting that MS "magically" transform the organizational behavior. In this paper, the author provides recommendations to harness the benefits of their MS.

Stallworth (2008) continued the studies of previous authors by analyzing the content of MS of Fortune 1000 higherperforming and lower-performing firms. The researcher reached the conclusion that the higher-performing firms included eight of the nine recommended components more often than the lowerperforming firms did, and the differences were significant for three of those components. Additionally, the author used textual analysis methods. The work identified strategies employed by these firms to create a strong identity (internal ethos) and image (external ethos). The two groups used similar strategies for building corporate identities and images, but they differed in the values they emphasized and the goodwill recipients they targeted.

Desmidt and Prinzie (2009) tackled with the real value of MS by carrying out an explorative analysis of their effectiveness. These authors put the emphasis on the communication perspective.

Powers (2012) provided guidelines for writing organizational MS, and a framework was presented to check where MS fits into the SPP.

In terms of the origin and perspective in its formulation, different authors offered different approaches. For instance, while Lundberg (1984), Baetz and Bart (1996), and Mullane (2002) prefer a manager-focused perspective focusing on the relevance of the managers as originators of MS, David (1989) and Orhan et al. (2014) prefer an employee-perspective approach in which MS is a key element for ensuring employees' alignment with the companies' goals and essence. More recently, David et al. (2014) have investigated from a marketing-oriented approach how a customer-focused perspective is convenient when MS is formulated.

David et al. (2014) highlight that MS should be:i) informative, ii) inspiring, iii) enduring, iv) concise, v) clear, and vi) conducive to both employees and customers forming an emotional bond with the firm.

In a similar way, Gaebler (2018) provides recommendations 
for the development of MS. This author emphasizes five common mistakes in its formulation: i) too long, ii) too boring, iii) too unbelievable, iv) too confusing, and v) too disingenuous.

Additionally, Quain (2018) reveals nine main characteristics that any MS should comply with: i) be short, ii) be unique to your business, iii) create expectations, iv) be realistic, v) be memorable, vi) be active, vii) be positive, viii) be adaptable, and ix) be targeted.

Finally, Alegre et al. (2018) stated that MS is a widely used strategic tool that emphasizes an organization's uniqueness and identity, and there is a general consensus on the need for explicitly formulating MS in organizations.

These authors selected and analyzed 53 articles developing a bibliometric and content analysis regarding MS. According to their perspective, the works selected were grouped into four thematic areas: i) MS development, ii) MS components, iii) MS impact on employees, and iv) MS impact on performance. The overreaching conclusion of this work is that MS's are widely used in practice, but poorly researched in theory. Most articles adopt a managerial phenomenon-based strand, lacking a deep theoretical foundation. The article ends with suggestions for further research in terms of theory, practice, and methodology on this topic.

To the best of our knowledge, there isn't any research focused on the formulation of MS in PA's.

\section{DATA}

In the context of the current work, a survey has been carried out covering the entire SPS. As a result of this research, it has been found that $86 \%$ (24 out of 28) of the Spanish Port Authorities (SPA) have made public their MS's, while the remaining $14 \%$ either keep it confidential or they had not formally elaborated it. A translation of all these MS's is provided as supplementary material.

\section{THEORY, CALCULATION AND METHODOLOGY}

MS's differ in four key elements: length, content, format, and specificity (Kemp and Dwyer, 2003; Palmer and Short, 2008; Smith et al., 2001).

In this work the two first key elements (length and content) have been used to assess the MS's of the SPA.

\subsection{Criterion 1 - Length Of Ms}

As described above, an ideal MS should meet certain criteria (to be unique, create expectations, be memorable, etc.) and include certain items (references to markets, services, selfconcept, etc.), which requires a minimum length. The shorter an MS is, the more difficult it is to meet all of the criteria and items.

On the other hand, other authors cited above emphasized the need of avoiding a too boring formulation of MS, and they recommend to formulate it in short and understandable terms.

It seems to be a typical "two sides of the coin view" paradigm. This topic has been addressed by several authors who have concentrated their efforts in determining what the most appropriate length of MS should be.

While some practitioners recommend short statements (Quain, 2018), others simply recommend that it has to be long enough (Clearlogic, 2018).

Some researchers suggest that MS is most effective when it is approximately 100 words in length, avoiding the inclusion of monetary amounts, numbers, percentages, ratios, or objectives (David and David, 2003; Davies and Glaister, 1997; Kemp and Dwyer, 2003).

Clearlogic (2018) highlights how the length of MS is dependent on the complexity of the organization and its goals. Additionally, those statements that are too long or too short will likely have less impact on employee behavior. If it is too long, "employees may not read the whole mission, or will have a harder time committing all its goals to memory", while if it is too short, "it likely is not detailed enough to describe how employees are expected to accomplish each goal." According to this author, based on his inspection of 100 Fortune 500 company MS's, the average length is about 45 words.

The problems related to too long an MS is also addressed by Gaebler (2018) in the following terms: "When it comes to the length of your mission statement, size definitely matters. If your mission statement is a long, drawn out description of every aspect of your company, no one is going to read it, let alone remember it. Your goal is to craft a mission statement that will make an impact and stick in your readers" minds long after they have turned the page. If your mission statement is too long, that simply isn't going to happen."

\subsection{Criterion 2 - Content of MS}

To analyze the content of MS's, different authors have used the nine attributes test developed by Pearce (1982), Pearce and David (1987) and David (1989).

The methodology used in this work is the one described in Kemp and Dwyer (2003), who followed this test. The authors adapted the research to the PA context. To this purpose, the following questions are made:

- Does MS identify the customers and markets?

- Does MS identify the services?

- Does MS identify the core technologies?

- Does MS specify the geographic domain?

- Does MS express PA commitment to survival, growth, and profitability?

- $\quad$ Does MS specify the key elements in the PA philosophy?

- Does MS identify PA self-concept (distinctive competence)? 
Table 1.

Analysis of the content of Mission Statements of the Spanish Port System.

\begin{tabular}{|c|c|c|c|c|c|c|c|c|c|c|c|}
\hline PORT AUTHORITY & LENGTH & C\&M & P\&S & L\&M & TEC. & $\cos$ & PHI & SC & CoE & Total & $\%$ \\
\hline A CORUÑA & 19 & 0 & 1 & 1 & 0 & 0 & 1 & 1 & 0 & 5 & $56 \%$ \\
\hline ALICANTE & - & - & - & - & - & - & - & - & - & - & - \\
\hline ALMERÍA & 33 & 1 & 1 & 0 & 0 & 0 & 1 & 1 & 0 & 5 & $56 \%$ \\
\hline AVILÉS & 18 & 1 & 1 & 0 & 0 & 1 & 1 & 0 & 0 & 5 & $56 \%$ \\
\hline $\begin{array}{l}\text { BAHÍA DE } \\
\text { ALGECIRAS }\end{array}$ & 27 & 1 & 1 & 0 & 0 & 1 & 1 & 1 & 1 & 7 & $78 \%$ \\
\hline BAHÍA DE CÁDIZ & 46 & 1 & 1 & 0 & 0 & 1 & 1 & 1 & 0 & 6 & $67 \%$ \\
\hline BALEARES & 28 & 0 & 1 & 1 & 0 & 0 & 1 & 1 & 0 & 5 & $56 \%$ \\
\hline BARCELONA & 31 & 1 & 1 & 1 & 0 & 0 & 1 & 1 & 0 & 6 & $67 \%$ \\
\hline BILBAO & 41 & 1 & 1 & 1 & 1 & 1 & 1 & 1 & 0 & 8 & $89 \%$ \\
\hline CARTAGENA & 18 & 1 & 1 & 1 & 0 & 0 & 0 & 0 & 0 & 4 & $44 \%$ \\
\hline CASTELLÓN & 39 & 1 & 1 & 0 & 0 & 1 & 1 & 1 & 0 & 6 & $67 \%$ \\
\hline CEUTA & 43 & 1 & 1 & 1 & 0 & 0 & 1 & 1 & 0 & 6 & $67 \%$ \\
\hline $\begin{array}{l}\text { FERROL-SAN } \\
\text { CIBRAO }\end{array}$ & 49 & 1 & 1 & 1 & 0 & 1 & 1 & 1 & 0 & 7 & $78 \%$ \\
\hline GIJÓN & 23 & 0 & 1 & 1 & 0 & 0 & 1 & 1 & 0 & 5 & $56 \%$ \\
\hline HUELVA & 38 & 0 & 1 & 1 & 0 & 0 & 1 & 0 & 0 & 4 & $44 \%$ \\
\hline
\end{tabular}

LAS PALMAS

MÁLAGA

MARÍN Y RÍA DE

PONTEVEDRA

\begin{tabular}{llllllllllll} 
MELILLA & 30 & 1 & 1 & 1 & 0 & 0 & 1 & 1 & 0 & 5 & $56 \%$ \\
MOTRIL & 29 & 0 & 1 & 1 & 0 & 1 & 1 & 1 & 0 & 5 & $56 \%$ \\
\hline PASAIA & 43 & 1 & 1 & 1 & 0 & 1 & 1 & 1 & 0 & 7 & $78 \%$ \\
$\begin{array}{l}\text { SANTA CRUZ DE } \\
\text { TENERIFE }\end{array}$ & 20 & 0 & 0 & 0 & 0 & 0 & 1 & 1 & 0 & 3 & $33 \%$ \\
\hline
\end{tabular}

\begin{tabular}{llllllllllll}
\hline SANTANDER & 27 & 1 & 1 & 0 & 0 & 0 & 1 & 1 & 0 & 5 & $56 \%$ \\
\hline SEVILLA & 19 & 0 & 1 & 0 & 0 & 0 & 0 & 1 & 0 & 2 & $22 \%$ \\
\hline TARRAGONA & 56 & 1 & 1 & 1 & 0 & 1 & 1 & 1 & 1 & 8 & $89 \%$ \\
\hline VALENCIA & 40 & 1 & 1 & 1 & 0 & 1 & 1 & 1 & 0 & 7 & $78 \%$ \\
\hline VIGO & 31 & 1 & 1 & 0 & 0 & 1 & 1 & 1 & 0 & 6 & $67 \%$ \\
\hline VILAGARCÍA & - & - & - & - & - & - & - & - & - & - & - \\
\hline TOTAL & 778 & 17 & 23 & 15 & 1 & 11 & 22 & 21 & 2 & - & - \\
\hline AVERAGE & 32.4 & $71 \%$ & $96 \%$ & $63 \%$ & $4 \%$ & $46 \%$ & $92 \%$ & $88 \%$ & $8 \%$ & 5.54 & $62 \%$ \\
\hline
\end{tabular}

This table shows the length of the Mission Statement of each Port Authority jointly with the number of attributes that are included in it. LEN is the length (words) of the Mission Statement, C\&M reflects the attribute "Customer and Market", P\&S reflects the attribute "Product and Services", L\&M is "Location and Market", TEC means "Technology", CoS means "Concern of Survival", PHI is "Philosophy", SC reflects the attribute "Self-Concept", CoE means "Concern of Employees", Total is the aggregate sum of the attributes reflected in each mission statement and \% is the percentage of attributes that are included in the Mission Statement. 
- Does MS identify the PA desired public image?

- $\quad$ Are the employees considered as a key element in the MS of a PA?

Each of the authors of this work independently recorded whether or not the MS of each PA captured each of the nine components identified above. Value "1" indicates that the MS includes reference to the component analyzed, and value " 0 " indicates that MS does not refer to this component in the MS of such a PA.

Following this individual assessment, the results were sent to the authors to re-assess their opinions respectively in view of the other authors' opinion. Once re-assessed, a second individual judgement was produced.

In a sort of Delphi Methodology, based on a second judgment, the authors finally met in order to discuss the results provided by each one specifically, those in which there was no possibility to reach an agreement about what the most appropriate descriptor ("1" or "0") was.

As a result of this process, a high consensus was reached among them getting the final assessment for each PA.

The results are compiled in Table 1 in which: i) the last column is the calculation of how many "1" are present in the MS of a PA, ii) the last row indicates how many PA's include such elements in their MS's.

\section{RESULTS AND DISCUSSION}

\subsection{Criterion 1 - Length of MS}

The length of the MS of each PA is included in the second column of Table 1. In the case of SPS, the average length of MS in SPS is about 32 words, with a standard deviation of 11 words.

The longest statement is that of Tarragona PA (56 words), while the shortest is the one of Avilés PA (18 words).

These results are not totally aligned with the authors cited above, and the length of 32 words in average is shorter than the 45 words recommended by Clearlogic (2018) or the 100 words length suggested by David and David (2003), Davies and Glaister (1997), Kemp and Dwyer (2003).

\subsection{Criterion 2 - Content of MS}

Analyzing the components used by PA's when formulating their MS's (Table 2), it has been figured out that the approach taken in SPS is basically customer or service oriented. In fact, $96 \%$ of the PA's explicitly include the product / services they provide in the statement. They are also very active in including their philosophy (92\%) and their concerns in terms of public image and self-concept (88\%). Customer / Markets (71 \%), Location / Markets (63\%), and concern for survival (46\%) are other topics that PA's typically use in their MS's. However, only one PA (4\%) cites technology / innovation in its MS, and two of them ( $8 \%$ ) consider employees dimension of the statement (it is not discussed herein whether employees have been actively involved in the formulation of the MS or not, but their concerns have been exclusively cited in the MS as any other element).

Table 2.

Number of mission statements that include each component.

\begin{tabular}{|c|c|c|c|}
\hline Component & Number & Percent. & Rank \\
\hline Customer / Markets & 17 & $71 \%$ & 5 \\
\hline Product / Services & 23 & $96 \%$ & 1 \\
\hline Location / Market & 15 & $63 \%$ & 6 \\
\hline Technology & 1 & $4 \%$ & 9 \\
\hline Concern for survival & 11 & $46 \%$ & 7 \\
\hline Philosophy & 22 & $92 \%$ & 2 \\
\hline Self-concept & 21 & $88 \%$ & 3 \\
\hline Concern for public image & 21 & $88 \%$ & 3 \\
\hline Concern for employees & 2 & $8 \%$ & 8 \\
\hline
\end{tabular}

This table shows how many each of the nine attributes of an "ideal" Mission Statement are included in the MS of SPS. The first column ("component") is the attribute, the second one ("number") in the total number of PA in which the attribute is included in its Mission Statement., the third one ("percentage") is the percentage of Port Authorities in which such attribute is included and the fourth "rank" is the ranking (i.e. the attribute with ranking 1 is the one more frequently found in the MS of SPS while the ranking 9 shows the attribute which is rarer in this system. 
Considering the number of components included in the MS's (Table 3), it is possible to conclude that $8 \%$ of the PA's only include two of them, while $17 \%$ take four, and $25 \%$ consider six of them. In the highest part of the score, one PA (4\%) covers eight out of nine components, and another PA (4\%) considers seven of them, while two PA's introduce six components. The most frequent case is the one in which a PA uses five components in its MS (eight PA's, which means one third of the total).

Table 3.

Number of components in each of the Port Authorities' mission statements.

\begin{tabular}{lll} 
Number of Components & Number of Ports & Percentage \\
\hline 9 & 0 & $0 \%$ \\
\hline 8 & 1 & $4 \%$ \\
\hline 7 & 1 & $4 \%$ \\
\hline 6 & 2 & $8 \%$ \\
\hline 5 & 8 & $33 \%$ \\
\hline 4 & 6 & $25 \%$ \\
\hline 3 & 4 & $17 \%$ \\
\hline 2 & 2 & $8 \%$ \\
\hline 1 & 0 & $0 \%$ \\
\hline 0 & 0 & $0 \%$ \\
\hline
\end{tabular}

This table shows the overall number of attributes which are included in the MS. The first column shows the overall number of components included, the second column shows the number of Port Authorities in which the "number of components" of this row is included, and the third column (percentage) is the percentage of Port Authorities that include the referred 'number of components". For instance, there are a total of eight (8) Port Authorities in Spain (33 \%) which include five (5) components in their Mission Statement (reference is made to the row number 6 of the Table).

In order to compare the content of the MS of the SPS with other environments, the authors have developed a benchmarking analysis comparing the results with two previous researches.

The first is the analysis that has given rise to this methodology (Pearce and David, 1989), based on a survey of $61 \mathrm{MS}^{\prime}$, and the second is the one developed by Dharmadasa et al. (2012), who carried out an analysis of 90 out of the 231 companies listed on the Colombo Security Exchange (CSE) of Sri Lanka (Table 4).

Three main conclusions can be highlighted:

First: MS's of the SPA reflect more frequently seven of the nine key elements than those 150 companies' analyses by Pearce and David (1989) and Dharmadasa et al. (2012). Only "technology" and "concern of employees" are the items in which SPA as a group develops poorer MS.

Second: The ranking of items covered by SPA is relatively similar to the ranking showed by high-performance firms in Pearce and Davis (1987). Three out of the first four topics in both cases are "philosophy", "self-concept", and "concern for public image".
Third: "Product / services" is the main topic covered by SPA and low performance firms and it is also the third element in the study carried out by Dharmadasa et al. (2012). However, it only reached number seven in the ranking provided by the high performance firms in Pearce and Davis (1987).

Another finding of this research is the relationship between the length of the MS and the number of these 9 components. Although the statically fit is not relevant $(r 2=0.52)$, there is some evidence that the longer the statement, the more components it includes. This is something that seems to be intuitive, but has been checked in order to verify if any of the studied PA's has made a long MS omitting several key elements or any PA has been able to capture many of them in a short MS. Simplifying things, those PA's with MS's below 25 words meet no more than 2-5 components, while those with more than 40 words always cover 6-8 elements and in an intermediate group between 25 and 50 words range between 4 and seven components (Figure 1). 
Table 4.

Benchmark Mission Statement Content.

\begin{tabular}{|c|c|c|c|c|c|c|c|c|}
\hline \multirow[b]{3}{*}{ Component } & \multicolumn{8}{|c|}{ Pearce and David (1989) } \\
\hline & \multicolumn{2}{|c|}{ PORT AUTHORITIES } & \multicolumn{2}{|c|}{$\begin{array}{l}\text { HIGH PERFORMANCE } \\
\text { FIRMS }\end{array}$} & \multicolumn{2}{|c|}{$\begin{array}{l}\text { LOW PERFORMANCE } \\
\text { FIRMS }\end{array}$} & \multicolumn{2}{|c|}{$\begin{array}{l}\text { Dharmadasa et al. } \\
\text { (2012) }\end{array}$} \\
\hline & $\%$. & Rank & $\%$ & Rank & $\%$ & Rank & $\%$ & Rank \\
\hline Customer / Markets & $71 \%$ & 5 & $47 \%$ & 6 & $60 \%$ & 4 & $34 \%$ & 5 \\
\hline Product / Services & $96 \%$ & 1 & $58 \%$ & 5 & $87 \%$ & 1 & $53 \%$ & 3 \\
\hline Location / Market & $63 \%$ & 6 & $42 \%$ & 7 & $33 \%$ & 7 & $15 \%$ & 8 \\
\hline Technology & $4 \%$ & 9 & $16 \%$ & 8 & $7 \%$ & 8 & $14 \%$ & 9 \\
\hline Concern for survival & $46 \%$ & 7 & $95 \%$ & 2 & $87 \%$ & 1 & $57 \%$ & 2 \\
\hline Philosophy & $92 \%$ & 2 & $89 \%$ & 3 & $60 \%$ & 4 & $43 \%$ & 4 \\
\hline Self-concept & $88 \%$ & 3 & $89 \%$ & 3 & $53 \%$ & 6 & $60 \%$ & 1 \\
\hline Concern for public image & $88 \%$ & 3 & $100 \%$ & 1 & $73 \%$ & 3 & $29 \%$ & 7 \\
\hline Concern for employees & $8 \%$ & 8 & $\mathrm{~N} / \mathrm{A}$ & N/A & $\mathrm{N} / \mathrm{A}$ & N/A & $37 \%$ & 6 \\
\hline
\end{tabular}

This table shows how often each of the key attributes of the MS are included in Port Authorities and how these percentages compare with other sectors, taking into consideration the works of Pearce and David (1989) and Dharmadasa et al. (2012). The first column ("component") is the key attribute, the second and third columns show the percentage and ranking within the Spanish Port Authorities. The fourth and fifth columns reflect the same concepts (percentage and ranking) in a selected group of High Performance firms included in Pearce and David (1989). The sixth and seventh columns are connected with same work but considering low performance firms. The last two columns are the outcome of Dharmadasa et al. (2012) studies.

\section{Mission Statements in Spanish Port System}

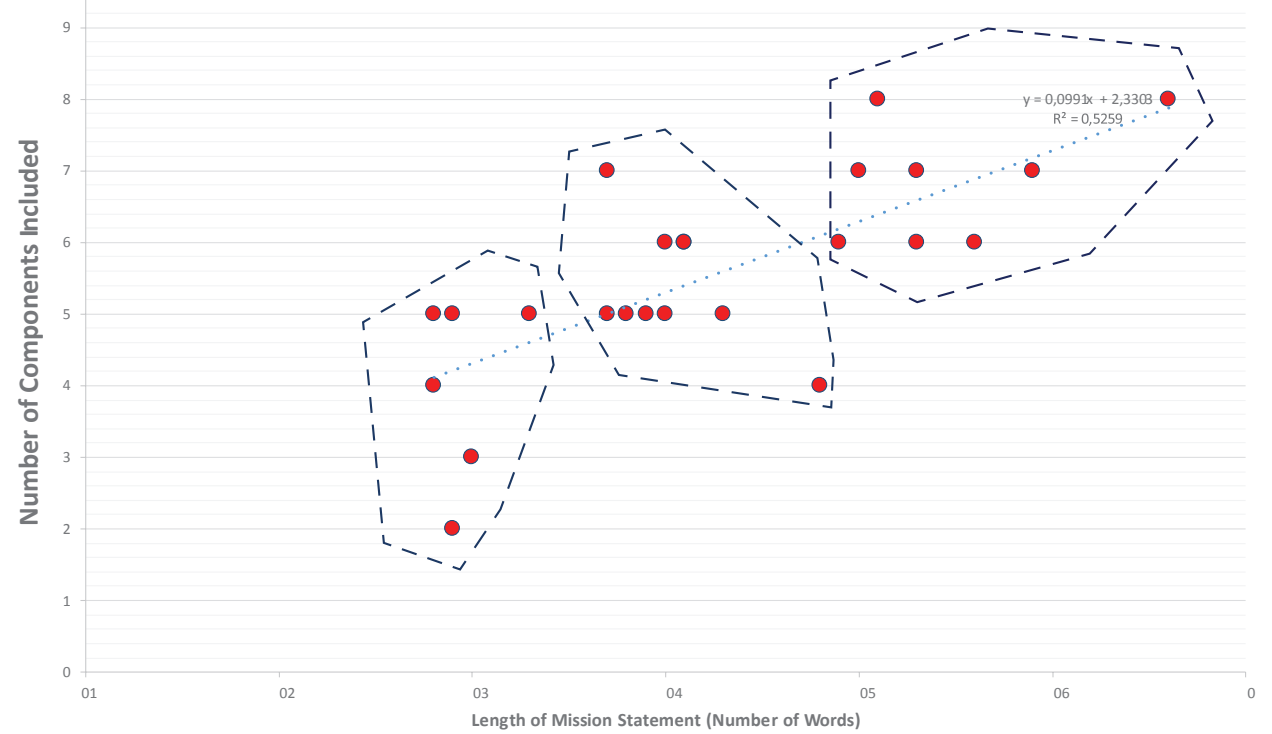

Figure 1.

Length and number of the components addressed in MS.

The figure shows the relationship between the length of the MS and the number of key attributes. Three main groups of Port Authorities can be found with short Missions (less than 25 words), medium length Missions (25-40 words) and long Missions (more than 40 words). Those with more words also include more key attributes (more than six), while those with shorter Statements include typically less than five. 
The final conclusion of this research is related to the semantic content of the statement (Table 5). The most used word / concept in the MS's is "port" with 26 occurrences, followed by "service(s)" with 20 occurrences, "development" with 12, and "economic" with 10. Far from this area [hinterland] is used 9 times, [add] value 8 times; "sustainable", "infrastructures", and "competitiveness" 7 times each and, finally, "influence" with 6 repetitions.

Table 5.

Semantic Analysis of Mission Statements.

\begin{tabular}{llll} 
Word & Occurrences & Frequency & Rank \\
\hline Port & 26 & $5.8 \%$ & 1 \\
\hline Service(s) & 20 & $4.5 \%$ & 2 \\
\hline Development & 12 & $2.7 \%$ & 4 \\
\hline Economic & 10 & $2.2 \%$ & 5 \\
\hline Area [hinterland] & 9 & $2.0 \%$ & 6 \\
\hline [add] Value & 8 & $1.8 \%$ & 7 \\
\hline Sustainable & 7 & $1.6 \%$ & 7 \\
\hline Infrastructures & 7 & $1.6 \%$ & 8 \\
\hline Competitiveness & 7 & $1.6 \%$ & 9
\end{tabular}

The table shows a semantic analysis of the MS of the Spanish Port Authorities. The key words are included in the first column ("word") jointly with the occurrence in the number of times that this word is included (column 2 - "occurrences"), and the" frequency" (column 3) of this word and its ranking (relative position being ranking 1- the most frequent word in the MS analyzed).

\section{CONCLUSION AND FUTURE RESEARCHES}

The SPS has developed an administrative and legal wellstructured SPP. As early as the 1990s, most of the PA's developed their own Strategic Plan and made public their mission and vision statement as well as their corporate values.

The MS of the SPA's are essentially market-oriented and they are well structured considering business practices in terms of their content. In fact, MS's formulated by SPA reflect more frequently than the benchmark comparison seven of the nine key elements.

The only two fields in which SPA's show a negative gap are those related to "technology" and "concern of employees". An in-depth study of the reasons for this deviation is of potential interest for future researchers.

In terms of the length of the statements, the average of 32 words of the SPS is shorter than the 50-100 words recommended by some authors as a general rule of thumb. An additional comparison with PA's of other countries is another potential area of interest in order to determine if this is a particularity of the SPS or there is a structurally justified reason for this which is applicable to these types of companies.

This work does not discuss the relationship between port performance (financial, operational, environmental, etc.) and the MS of each PA. It is another limitation of the study and it provides and interesting direction for further and future research. For instance, it is not the goal of this work to assess if port size impacts the formulation of the MS or if there is any similarity in the MS's of the PA's if port competitiveness is considered (i.e. if competing PA's develop similar MS's or, at least, they capture the same key elements). This represents a new opportunity for future researchers.

\section{REFERENCES}

AAPA, 1988. Strategic Planning: A guide for port industry. American Association of Port Authorities, Alexandria, Virginia, USA.

Alegre, I., Berbegal-Mirabent, J., Guerreo, A., and Mas-Machuca, M., 2018. The real mission of the mission statement: A systematic review of the literature, Journal of Management and Organization, 24(4), pp.456-473. Available at: https://doi. org/10.1017/jmo.2017.82.

Amato, C.H., \& Amato, L.H., 2002. Corporate commitment to quality of life: Evidence from company mission statements. Journal of Marketing Theory and Practice, 10(4), pp. 69-87. Available at: https://doi.org/10.1080/10696679.2002.11501927.

Aparisi, J.A., Giner, A., and Pérez, E.M., 2009. Evidence of implementing a strategic management System at the Port Authority of Valencia. Global Journal of Business Research, 3(2), pp.93-116.

Atrill, P., Omran, M., and Pointon, J., 2005. Company mission statements and financial performance, Corporate Ownership and Control, 2(3), pp.28-35. Available at: https://doi.org/10.22495/cocv2i3p3. 
Baetz, M.C., \& Bart, C.K., 1996. Developing mission statements which work. Long Range Planning, 29(4), pp. 526-533, Available at: https://doi.org/10.1016/00246301(96)00044-1.

Baetz, B., \& Kenneth, C., 1998. The relationship between mission statements and firm performance: An exploratory study, Journal of Management Studies, 35(6), pp. 823-853. Available at: https://doi.org/10.1111/1467-6486.00121.

Bart, C.K., 1997. Sex, lies, and mission statements. Business Horizons, 40(6), pp.9-18. Available at: http://dx.doi.org/10.1016/s0007-6813(97)90062-8.

Bart, C.K., and Baetz, M., 1996. Developing Mission Statements Which Work, Long Range Planning, 29(4), pp.526-533. Available at: https://doi.org/10.1016/00246301(96)00044-1.

Bart, C.K., and Hupfer, M., 2004. Mission statements in Canadian hospitals. Journal of Health Organization and Management, 18(2), pp. 92-110. Available at: https://doi. org/10.1108/14777260410538889.

Bart, C.K., Bontis, N., and Taggar, S., 2001. A model of the impact of mission statements on firm performance, Management Decision, 39(1), pp. 19-35. Available at: https://doi.org/10.1108/eum0000000005404.

Bartkus, B.R., Glassman, M., and McAfee, B., 2006. Mission statement quality and financial performance. European Management Journal, 24(1), pp. 86-94. Available at: https://doi.org/10.1016/j.emj.2005.12.010.

Campbell, A., 1997. Mission Statements, Long Range Planning, 30(6), pp.931-932. Available at: https://doi.org/10.1016/S0024-6301(97)00084-8.

Campbell, A., and Yeung, S., 1991. Creating a sense of mission. Long Range Planning, 24(4), pp. 10-20. Available at: https://doi.org/10.1016/0024-6301(91)90002-6.

Capon, N., Farley, J.U. and Hoening, S., 1990. Determinants of financial performance: A meta-analysis. Management Science, 36(10), pp.1143-1159. Available at https:// doi.org/10.1287/mnsc.36.10.1143.

Clearlogic (2018), Developing Vision and Mission Statements that Inspire Action. Available at: http://clearlogic.ca/developing-vision-and-mission-statements-thatinspire-action/, accessed on: 12 April 2019.

David, F.R., 1989. How companies define their mission. Long Range Planning, 22(1), pp.90-97. Available at: https://doi.org/10.1016/0024-6301(89)90055-1.

David, Forest-R., and David, Fred-R., 2003. It's time to redraft your mission statement, Journal of Business Strategy, 24(1), pp.11-14. Available at: https://doi. org/10.1108/02756660310508218.

David, M.E., David Forest-R., and David Fred-R., 2014. Mission Statement Theory and Practice: A content analysis and new direction, International Journal of Business, Marketing, and Decision Science, 7(1), pp. 95-110. Available at: http://strategyclub. com/wp-content/uploads/2014/09/David-pdf-file.pdf

Davies, S.W., and Glaister, K.W., 1997. Business school mission statements - The bland leading the bland? Long Range Planning, 30(4), pp. 594-604. Available at: https://doi.org/10.1016/S0024-6301(97)00038-1.

Desmidt, S., and Prinzie, A., 2009. Does your mission statement have any value? An explorative analysis of the effectiveness of mission statements from a communication perspective. Available at: http://wps-feb.ugent.be/Papers/wp_09_568.pdf

Desmidt, S., Prinzie, A., and Decramer, A., 2011. Looking for the value of mission statements: A meta-analysis of 20 years of research. Management Decision, 49(3), pp. 468-483. Available at: https://doi.org/10.1108/00251741111120806.

Dharmadasa, P., Maduraapeurma, Y. \& Herath, S.K., 2012. Mission statements and company financial performance revisited. International Journal of Managerial and Financial Accounting, 4(3), p.314. Available at: http://dx.doi.org/10.1504/ ijmfa.2012.047855.
Hague, D.C. \& Drucker, P., 1974. Management. Tasks, Responsibilities, Practices. The Economic Journal, 85(337), p.195. Available at: http://dx.doi.org/10.2307/2230551.

Enríquez, F., 1993. El Plan Estratégico, Un instrumento para la gestión portuaria, Instituto Portuario de Estudios y Cooperación (IPEC), Valencia, Spain.

Estrada, J.L., 2007. Mejora de la competitividad de un puerto por medio de un modelo de gestión de la estrategia aplicando el Cuadro de Mando Integral. PhD Thesis, Universidad Politécnica de Madrid. Available at: http://oa.upm.es/535/1/ JOSE_LUIS_ESTRADA_LLAQUET.pdf

Gaebler, 2018. Mission Statement Mistakes. Available at: http://www.gaebler.com/ Mission-Statement-Mistakes.htm

Genç, K.Y., 2012. The Relation between the Quality of the Mission Statements and the Performances of the State Universities in Turkey. Procedia - Social and Behavioral Sciences, 58, pp.19-28. Available at: http://dx.doi.org/10.1016/j.sbspro.2012.09.974.

Germain, R., and Cooper, M.B., (1990), How a customer mission statement affects company performance, Industrial Marketing Management, 19(1), pp. 47-54, available at: https://doi.org/10.1016/0019-8501(90)90027-S.

Green, K.W.Jr and Medlin, B., 2003. The strategic planning process: The link between mission statement and organizational performance. Academy of Strategic Management Journal, 2(1), pp. 23-32.

Hirota, S. et al., 2010. Corporate mission, corporate policies and business outcomes: evidence from Japan. Management Decision, 48(7), pp.1134-1153. Available at: http://dx.doi.org/10.1108/00251741011068815.

Kaplan,R.S., and Norton,D., 1992. The balanced scorecard: Measures that drive performance. Harvard Business Review,70(1), pp. 71-79.

Kemp, S., and Dwyer, L., 2003. Mission statements of international airlines: $A$ content analysis. Tourism Management, 24(6), pp. 635-653. Available at: https://doi. org/10.1016/S0261-5177(03)00049-9.

King, W.R., and Cleland, D.I., 1979. Strategic Planning and Policy, Van Nostrand Reinhol, New York, USA.

Leuthesser, L. \& Kohli, C., 1997. Corporate identity: The role of mission statements. Business Horizons, 40(3), pp.59-66. Available at: http://dx.doi.org/10.1016/s00076813(97)90053-7.

Lundberg, C.C., 1984. Zero-in: A technique for formulating better mission statements. Business Horizons, 27(5), pp.30-33. Available at: https://doi.org/10.1016/00076813(84)90038-7.

Macedo, I.M., Pinho, J.C. \& Silva, A.M., 2016. Revisiting the link between mission statements and organizational performance in the non-profit sector: The mediating effect of organizational commitment. European Management Journal, 34(1), pp.3646. Available at: http://dx.doi.org/10.1016/j.emj.2015.10.003

Medley, G.J., 1992. WWF UK creates a new mission. Long Range Planning, 25(2), pp.63-68. Available at: https://doi.org/10.1016/0024-6301(92)90193-6.

Mullane, J.V., 2002. The mission statement is a strategic tool: when used properly, Management Decision, 40(5), pp.448-455. Available at: https://doi. org/10.1108/00251740210430461.

O'Gorman, C., and Doran, R., 1999. Mission statements in small and medium-sized businesses. Journal of Small Business Management, 37 (1), pp. 59-66.

Orhan, G., Erdoğan, D., and Durmaz, V., 2014. Adopting Mission and Vision Statements by Employees: The Case of TAV Airports. Procedia - Social and Behavioral Sciences, 150(15), pp. 251-262. Available at: https://doi.org/10.1016/j.sbspro.2014.09.051.

Palmer, T.B., and Short, J.C., 2008. Mission statements in U.S. colleges of business: An empirical examination of their content with linkages to Configurations and 
Performance, Academy of Management Learning \& Education, 7(4), pp.454-470. Available at: https://doi.org/10.5465/amle.2008.35882187.

Pearce, J.A., 1982. The company mission as a strategic tool, Sloan Management Review, 23(3), pp. 15-24

Pearce, J.A., and David, F.R., 1987. Corporate mission statements: the Bottom Line. Academy of Management Executive, 1(2), pp.109-116. Available at: https://doi. org/10.5465/ame.1987.4275821.

Powers, E.L., 2012. Organizational mission statement guidelines revisited. International Journal of Management \& Information Systems, 16(1), pp.281-290. Available at: https://doi.org/10.19030/ijmis.v16i4.7304.

Pradeep, D., Maduraapeurma, Y., and Herath, S., 2012. Mission statements and company financial performance revisited. International Journal of Managerial and Financial Accounting, 4(3), pp. 314-324, Available at: https://doi.org/10.1504/ ijmfa.2012.047855.

Puertos del Estado, 2001. Proceso de planificación estratégica: la experiencia de Puertos del Estado III [Strategic PLanning Process: The experience of Spanish State Ports], Puertos, 86(1), pp. 9-15.

Quain S., 2018.9 Characteristics of an Effective Mission Statement. Available at: http:// smallbusiness.chron.com/9-characteristics-effective-mission-statement-18142. html
Rajasekar, J., 2013. A Comparative Analysis of Mission Statement Content and Readability, Journal of Management Policy \& Practice, 14(6), pp. 131-147.

Rarick, C.a., and Vitton, J., 1995. Corporate Strategy: Mission Statements Make Cents, Journal of Business Strategy, 16(1), pp.11-12. Available at: https://doi.org/10.1108/ eb039673.

Sashittal, H., and Tankersley, C., 1997. The strategic market planning-implementation interface in small and midsized industrial firms: An exploratory study. Journal of Marketing Theory and Practice, 5(3), pp.77-92. Available at: https://doi.org/10.108 0/10696679.1997.11501772.

Smith, M., Heady, R.B., Carson, P., and Carson, K.D., 2001. Do missions accomplish their missions? An exploratory analysis of mission statement content and organizational longevity. The Journal of Applied Management and Entrepreneurship, 6(1), pp. 7596.

Stallworth, L.S., 2008. The mission statement: A Corporate Reporting Tool with a Past, Present and Future, International Business of Journal Communication, 45(2), pp. 94-119. Available at: https://doi.org/10.1177/0021943607313989.

UNCTAD, 1993. Strategic Planning for Port Authorities, Report UNCTAD/SHIP/646, United Nations Conference on Trade and Development, (UNCTAD), Genève Switzerland. Available at: http://unctad.org/en/Docs/shipd646_en.pdf. 